\title{
5.6
}

\section{The basic structure of the devolution settlements}

Devolution encompasses a range of quite different solutions in three countries (Scotland, Wales and Northern Ireland), plus markedly smaller delegations of powers to London and some English cities and regions. There remain important issues around the stability and effectiveness of these arrangements, which were designed to meet specific demands for national or regional control and to bring government closer to citizens. Diana Stirbu and Patrick Dunleavy explore how far relations between Westminster and the key devolved institutions have been handled democratically and effectively.

\section{What does democracy require of the UK's devolution arrangements?}

$\checkmark$ Devolved institutions must be representative and legitimate. They must rely upon freely and fairly elected institutions, built on and promoting democratic principles. Regional and local democracy should bring decision-making closer to the citizens. Devolved institutions should be created with popular endorsement to strengthen their legitimacy.

Devolution arrangements should be transparent and intelligible to the people they serve. The powers and competences devolved (that is, what functions are exercised and by whom) should be clear and comprehensible to the wider public. And the relationship between devolved authorities and the central government should be easy to follow. Clear and coherent devolution arrangements are essential if the general public are to hold decision-makers accountable. They are also key for policy actors at all levels of government in fostering more effective decision-making.

$\downarrow$ Under the principle of subsidiarity genuine scope for decision-making should be located as close to citizens (as low down in a governance hierarchy) as possible. This is to ensure that decisions attract consent, and interventions take place at the most effective and appropriate level of intervention.

Autonomous development is best fostered where devolved institutions can decide on their own democratic arrangements - such as setting their electoral arrangements and the size and nature of their political institutions. 
$\checkmark$ Devolved institutions should be inclusive, and promote citizen participation by creating new venues and mechanisms for engagement on a wide range of issues: from early constitutional deliberation on the form and nature of self-governance adopted, through to the final policy-making process within the new system.

$\checkmark$ Democratically elected institutions must be able to effectively scrutinise the exercise of power at their appropriate level of government.

$\downarrow$ Constitutional and (or) legal protection is needed if democratic devolution is to work, requiring a formal, fair and clear mechanism for resolving disputes over powers and competencies between tiers of government. A system of inter-governmental and inter-parliamentary relations is needed to facilitate dialogue and negotiation between the different levels of authority.

$\diamond$ Building new institutions takes a long time. So the arrangements of devolved governance should be durable and resilient in the face of political changes internally in their country or region, and at the UK level.

Most liberal democracies of any size in the modern world have moved away from being run as 'unitary states', with just one main centre of government plus a set of clearly subordinated local or regional authorities. For instance, some big European countries, like France, Italy and Spain, now have constitutionally protected regional governments, where before they were previously run as centralised Bonapartist states. Other liberal democracies are longstanding federal systems, notably Germany, the USA, Canada and Australia. So the UK's rapid movement since 1997 towards creating more devolved government is something of a belated falling into line with wider trends in other medium to large democracies.

However, the UK follows a pattern of 'organic' devolution with varying powers decentralised to different countries and regions. This approach is very different from a federal state.

Figure 1a shows that under federalism a written constitution (one that is normally fixed and hard to change) specifies just two 'bundles' of powers and competences. The first bundle is allocated to the federal or central tier, and the second bundle to the component states. All the states in federations have the same powers. The character of these allocations, along with the development of tax-raising powers and financial capacity at the two tiers, then create a system of inter-governmental relations.

How does change happen in federations? The federal centre may pick up new functions not specified in the constitution, and it may equalise financial capacities across states. It can also subsidise the states to do things on its behalf, or otherwise intervene in society. But it cannot (easily) change the constitution's existing allocation of functions. So the federal tier can only realise policy objectives that clearly fall within bundle 2 by persuading or incentivising the states who 'own' those issues. In addition, a Supreme Court polices the activities of both tiers of government impartially, and impartially regulates intergovernmental relations. 
Figure 1a: How a federal government system works

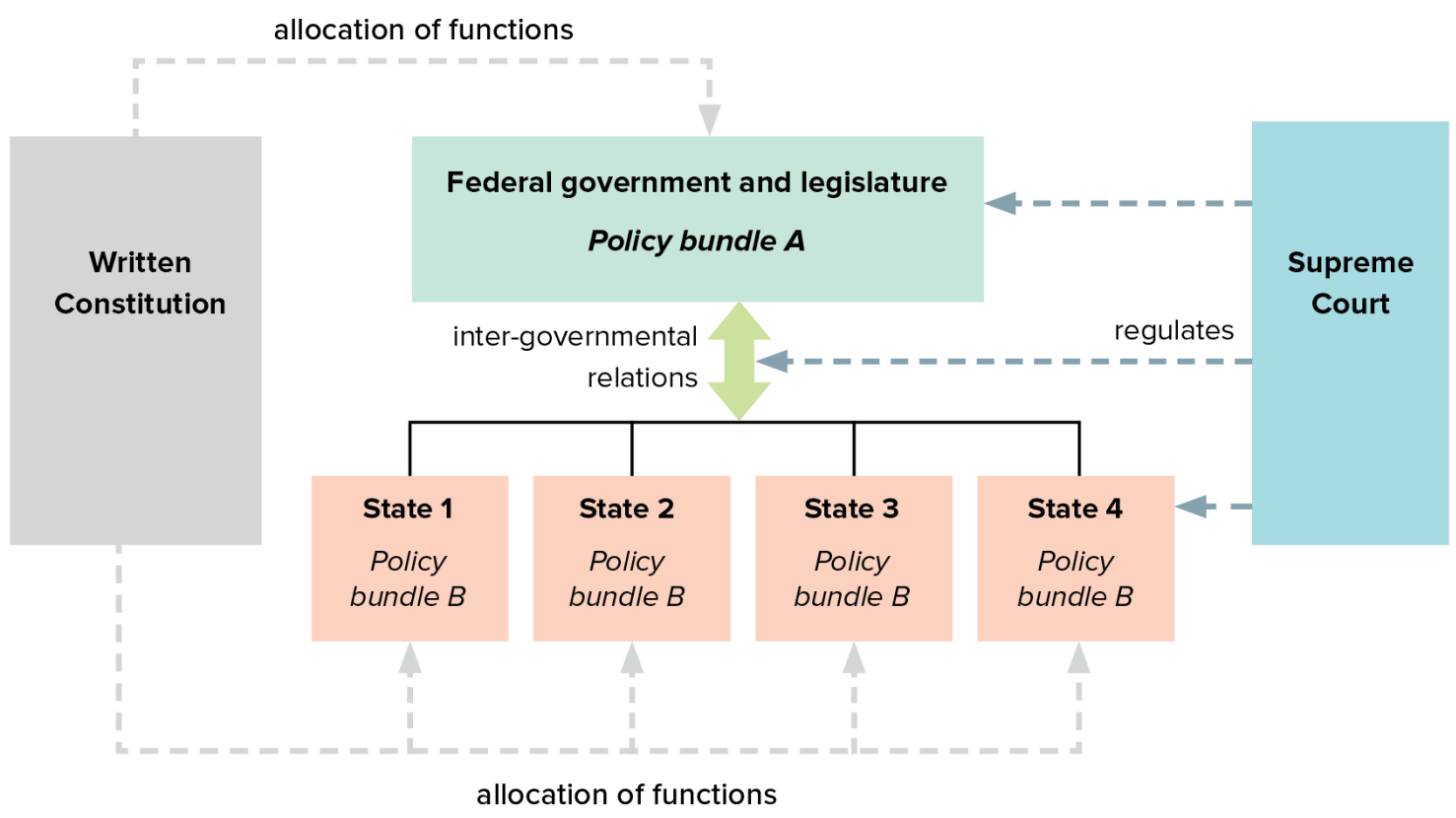

By contrast, in the UK there is no written constitution, and the foundational principle of 'parliamentary sovereignty' still implies that the Westminster Parliament 'cannot bind itself' legally (see Chapter 5.1). Alongside this, the highly political nature of the constitution allows for organic development to happen over time without the constraints of traditional constitutional amendment. A set of major policies (especially defence, foreign affairs, and most tax-raising and welfare) are 'reserved powers' belonging solely to the UK centre. Different sets of policy functions have been devolved to national institutions in Scotland, Wales and Northern Ireland, in ways that politically seem binding, and may provide some constitutional protections to these governments. Yet as Mark Elliot has observed: 'As a matter of strict law, the UK Parliament has merely authorised the devolved legislatures to make laws on certain matters, without relinquishing its own authority to make law on any matter it chooses - including devolved matters'. As we discuss below, Westminster actually still legislates changes that affect devolved policy areas, albeit so far with the consent of the devolved countries' legislatures.

The extent to which devolved powers in Scotland, Wales and Northern Ireland are protected constitutionally is still somewhat obscure, and the picture is different in each area, and has changed rapidly. The Scotland Act 1998 (and as amended since, most recently in 2016) set things up so that unless a policy area was explicitly reserved to Westminster then across most internal or domestic fields (excluding tax, social security and trade) all responsibilities within Scotland belonged by default to the Edinburgh Parliament and government. By contrast, in Wales a list of powers was initially just given as 'conferred matters' that the Cardiff Assembly and government could run. In 2017 a new Wales Act moved towards the Scottish model, so that in a (more restrictive) list of areas the Assembly is now the default legislature. 


\section{Figure 1b: The UK's devolved government system}

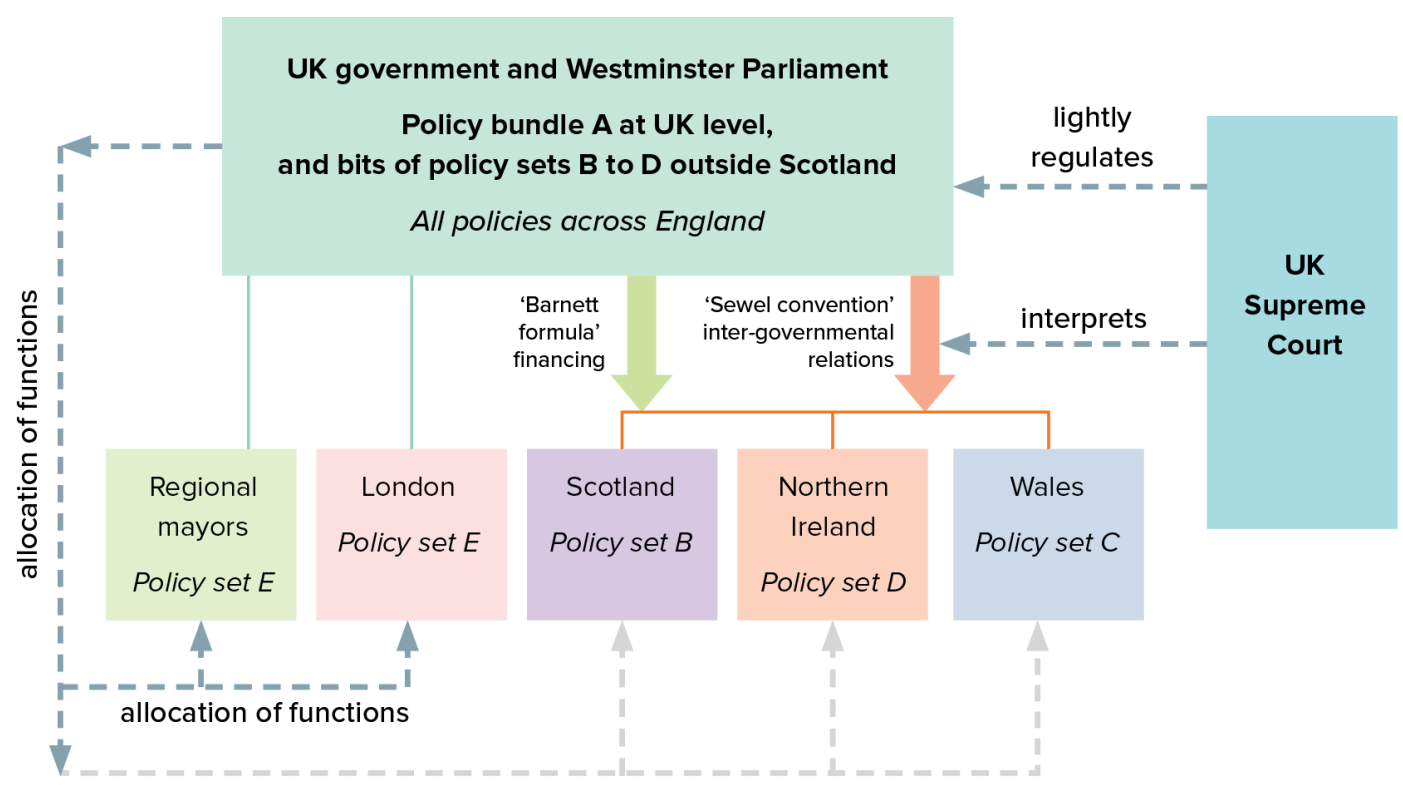

(varying) allocation of functions

In Northern Ireland there is a legacy (imperial-type) provision for devolved powers to be suspended and then taken over and run solely by the Westminster government - and this 'direct rule' situation applied from 1972, when the old Stormont model folded, until 1998 when the Northern Ireland Executive and Assembly first began operating. Since February 2017 the Assembly and Executive have been suspended because of political deadlock (see below), but (in theory) the devolved institutions remain in being and direct rule has not been formally triggered. This has left the Northern Ireland civil service to operate established policies on a 'caretaker basis' without any (explicit) political control.

Within England extensive powers have been devolved to the executive mayor and London Assembly in London, and lesser sets of powers to executive mayors in some city regions. However, Westminster retains an (almost) untrammeled ability to alter who is responsible for any policy function within England.

There is also an as yet unsophisticated system of inter-governmental relations within the UK, in which Westminster/England is the dominant player, accounting for five-sixths (85\%) of the population. There are only two key co-ordination mechanisms. First, most taxes are raised by the UK government, and it then allocates funding to the three devolved countries using a crude, fixed rule-of-thumb known as the 'Barnett formula'. The three devolved countries get funding as a fixed ratio of English spending. So if the UK government cuts or raises public expenditure in England, the same happens to the transfers from Westminster to fund the devolved governments' services.

Second, the UK centre has recognised a convention (named after a peer, Lord Sewel) which says that Westminster will not pass laws falling within the policy sets or responsibilities 
of Scotland, Wales or Northern Ireland without the consent of their legislatures and governments. The Scotland Act 2016 and the Wales Act 2017 embodied the Sewel convention in statute law for the first time, which was seen as a symbolic under-pinning for the permanence of the Scottish Parliament and the National Assembly for Wales. What this means in practice is much debated (see below).

The UK's Supreme Court has begun to play a key role in regulating inter-governmental relations between Westminster/Whitehall and the devolved governments. The Court is independent of Whitehall, and can in principle regulate how the centre behaves. But it has historically done so only in rather a light touch way, deferring to the need for a (national) executive government to operate effectively.

\section{Recent developments: Brexit battles}

In the Brexit referendum Scotland and Northern Ireland, plus the devolved city-region in London (with roughly the same population size as the other two combined), all voted strongly to remain in the EU. But most of the rest of England and Wales voted to leave. In the lead-up to the March 2017 triggering of formal 'leave' processes under the EU's Article 50 a Joint Ministerial Committee (JMC) of the three devolved countries and Whitehall ministers was resurrected by the May government to facilitate dialogue and consultation. (The Committee had previously been in abeyance.) It had some success on making progress on detailed issues, but also generated a lot of dissatisfaction. A series of key intergovernmental disputes have occurred throughout the Brexit process. The legal fog around the varying allocations of powers between tiers of government in the UK noted above remains pretty intense still because in essence:

$\checkmark$ On the one hand the Brexit process involves the UK as a whole leaving behind a series of international treaty obligations, and treaty-making is clearly a Westminster reserved function;

in addition, Westminster ministers argue that where a common policy previously applied within the EU to the whole UK territory (as with international trade) then for economic integration reasons it must continue to have a common policy stance post-Brexit.

However,

on the other hand, many of the EU powers that are being repatriated under Brexit cover areas, such as agriculture, fisheries, transport, regional development and infrastructure, that clearly fall within the ambit of the devolved government in Scotland and (to a lesser degree) Wales.

Figure 2 summarises a complex series of battles that have taken place since June 2016, up to the time of writing (September 2018). 


\section{Figure 2: Three Brexit battles involving the devolved governments}

\begin{tabular}{l|l}
$\begin{array}{l}\text { Issue or } \\
\text { case }\end{array}$ & $\begin{array}{l}\text { What the Scottish, Welsh and } \\
\text { Westminster governments argued }\end{array}$ \\
\hline Miller case & $\begin{array}{l}\text { In December } 2016 \text { Gina Miller argued } \\
\text { at the Supreme Court that the UK } \\
\text { government could not trigger Article 50 } \\
\text { to leave the EU without getting approval } \\
\text { from the Westminster Parliament. } \\
\text { Ministers argued that they did not need } \\
\text { parliamentary approval, but lost this issue. }\end{array}$
\end{tabular}

The devolved governments supported the Miller challenge, and raised the supplementary question of whether, if Parliament were to so legislate, would that Act require the consent of the devolved legislatures? UK ministers argued that, because leaving the EU was a treaty matter, it fell wholly within their reserved powers. This was the first legal challenge around the Sewel convention.
EU

Withdrawal Act 2018

Both devolved governments argued that the Act could not proceed without the consent of their legislatures, because many of the powers transferred back from the EU to the UK related to policy areas where they have default responsibilities. Leaving UK ministers to decide where repatriated powers should sit between Westminster and the devolved governments could unilaterally alter the balance of UK-tier versus devolved-tier powers.

The UK government argued that some filtering at UK level was needed to maintain UK-wide policies in its areas of reserved powers, but that agreement would be reached with the devolved governments.

\section{Continuity Bills}

\section{What happened?}

The result was disappointing for the devolved governments. The Supreme Court concluded rather ambiguously:

[T]he UK Parliament is not seeking to convert the Sewel Convention into a rule which can be interpreted, let alone enforced, by the courts; rather, it is recognising the convention for what it is, namely a political convention, and is effectively declaring that it is a permanent feature of the relevant devolution settlement' (p.48).

The Scottish Parliament voted in summer 2018 to withhold consent for the EU Withdrawal Act, supported by all parties except the Scottish Conservatives. The issue of whether Westminster can proceed without Edinburgh's consent will be tested in the courts.

The Welsh government initially sided with Scotland, but later agreed to the broad legal framework proposed by Westminster - and on a process for working through the details of which powers will be devolved to them and when (which is not yet clear). Wales then withdrew its opposition to the Act.

As part of its agreement with UK ministers on the process for transferring powers, the Welsh government promised to repeal their continuity statute.

The Scottish government maintained the legality of their continuity statute and the issue was before the UK

Supreme Court at the time of writing. 
The process has become acrimonious in large part because, critics argue: 'The devolved governments have been largely excluded from the process of defining the UK's approach to Brexit and its negotiations with the EU, despite early promises by Westminster to the contrary. How this major clash of constitutional claims, and the continuing Scotland/UK dispute over Brexit processes, will be decided remains unclear. But some resolution will be needed before the end of 2018.

Meanwhile, of course, since February 2017 the Northern Ireland Executive and Assembly have been suspended, leaving UK ministers simply talking directly and separately with political parties there about how powers will be transferred post-Brexit.

\section{Recent developments: the growth of devolved powers}

Scotland: In the 2014, Scottish independence referendum voters chose to remain in the UK by $55 \%$ to $45 \%$, but only after the Prime Minister David Cameron had promised major new powers for Scotland's government. Devolution of tax-raising powers to Scotland has always been important in the context of enhancing the Edinburgh government's autonomy and salience for voters. It was the centrepiece of both the 2014 Smith Commission Report, and the 2016 Scotland Act. This gave Edinburgh new powers to set air departure tax, to make an add-on to income tax rates and vary its thresholds, and to control various land and building taxes. The proportion of the Edinburgh government's budget raised directly in Scotland will increase from $10 \%$ in $2014-15$ to $52 \%$ by 2020.

In the area of social security, the Scottish government gained new powers over carers' and disability welfare benefits, on topping-up reserved benefits run by the UK, and on creating new benefits (see below). In April 2018 the Edinburgh Parliament unanimously approved the SNP government's proposals for Scotland to take over administration of these parts of social security spending, which will cost $£ 2.8$ bn annually by 2021 . The benefits covered are chiefly those for elderly and disabled people - personal independence payments, carer's allowance, attendance allowance, disability living allowance and other disability benefits, winter fuel and cold weather payments, maternity grants and discretionary housing payments. This will be a substantial change: 'When the social security powers are in place, [the Scottish government] expects to process as many [benefits] transactions in a week as it currently does in a year'.

In Whitehall, raising taxes and paying out social security have long accounted for around half of the UK civil service and a similarly large chunk of running costs. The Westminster government transferred $£ 200 \mathrm{~m}$ to cover the transition costs for Edinburgh as it takes over these responsibilities, but Audit Scotland found that the total transition bill is likely to cost a further $£ 60 \mathrm{~m}$. This seems a relatively small sum for the scale of changes, shedding an interesting light on the likely transition costs of Scotland becoming an independent state, which created controversy during the 2014 referendum. A 2018 SNP Commission Report (drawing on analysis by Dunleavy at Annex B5) found that transition costs will be modest. By 2021 Scotland will already have substantial tax and social security administrations fully in place. So the additional administrative costs involved in Scotland going independent in future could be further lessened. (For Scotland, see also Chapter 6.1.) 
Wales: The Wales Act 2017 also marks a significant reshaping of the Welsh constitutional settlement with a transfer of additional powers (for example over energy and harbours) and more autonomy for the Assembly in dealing with its own affairs, by devolving electoral franchise and powers over the size of the Assembly to Wales. Welsh ministers can now borrow up to £1bn for capital spending without needing Whitehall permission. And (like Scotland) the Cardiff Assembly and government now have default control over any policy area not specifically retained by Westminster. They have notably gained extra powers to regulate transport. An interesting development occurred in 2017 when the Assembly passed an Act that (taken at face value, and if upheld by the courts) disapplies in Welsh public services some provisions of a 2016 Westminster trade union law.

However, the likely durability and robustness of the Wales Act was criticised heavily, both while the law was under legislative scrutiny and after receiving Royal Assent. Constitutional preferences amongst citizens in Wales point to strong support for greater autonomy. Given the choice between the 'Assembly to have more powers / Assembly to have same powers as now', the largest group of respondents to the regular BBC/ICM St David's Day Poll in March 2017 chose more powers.

With the new powers to self-regulate Welsh affairs, the Presiding Officer of the National Assembly appointed an expert panel on Assembly electoral reform, which reported back in December 2017 recommending an increase in the Assembly size (to 80-90 AMs), lowering the voting age to 16- and 17-year-olds, changing the electoral system and introducing prescriptive legislative gender quotas. The Assembly commission's follow-up consultation (in 2018) sought the views of the Welsh public on these recommendations and will introduce legislative proposals in two stages to further shape the Welsh constitutional settlement (see Chapter 6.3).

Northern Ireland: The devolution settlement in Northern Ireland has not been working as intended since February 2017, when the top two parties (the Democratic Unionist Party and Sinn Féin) could not agree to form a power-sharing Executive (see Chapter 6.5). Despite new elections in March 2017, the Executive and Assembly remain suspended. If and when the reduced size Assembly (cut from 108 to 90 seats in 2016) and Executive restart, then some of its powers (on welfare reform, and corporation tax) have also been increased.

England: The process here long focused on the already powerful executive London mayor (and Greater London Authority), who is acquiring (over the next few years) commissioning, strategic planning, funding and regulation powers in health and social care. Outside the capital, new governance and leadership arrangements focusing on regional or metro mayors emerged piecemeal from 2014 onwards, initially in the absence of a clear legislative framework. The 2016 Cities and Local Government Devolution Act streamlined this process, and to date 11 devolution deals have been negotiated, and seven of them started working with direct mayoral elections in 2017 and 2018 (see Chapter 6.9).

Some wide-coverage English devolution deals include areas such as all urban transport and infrastructure, health, skills and employment, enterprise and growth, housing, planning fire services - as in Greater Manchester with a powerful executive mayor. More modest deals bracketed as 'devolutionary' (because Whitehall has given up some powers) range 
from combined authorities spanning city regions and led by an executive mayor (as in Liverpool City region) to combined authorities with a new elected mayor with much fewer powers (as in Cambridge and Peterborough), down to a unitary council and local economic partnership model (Cornwall).

\section{Strengths, Weaknesses, Opportunities, Threats (SWOT) analysis}

\section{Current strengths}

Devolution appears to be firmly entrenched in the national polities in Scotland and Wales, and also in London. Lesser devolution to elected regional or metro mayors has expanded radically within England in 201718. Northern Ireland's arrangements are not operating currently, but may restart, and retain basic support from voters there.

Electoral systems used in the mainland devolved administrations (Scotland, Wales and London) secure broadly proportional representation (see Chapter 2.2). They arguably redress some of the representational defects inherent to Westminster's plurality rule (FPTP) system.

The supplementary vote system used to elect the London mayour and new regional and metro mayors has also worked well to maximise their legitimacy.

Some devolved legislatures have better records on gender representation than Westminster (see Chapter 7.2). There have never been under $40 \%$ women members in Wales, and never been under $30 \%$ in Scotland. Northern Ireland is still somewhat a laggard.

All the devolved legislatures and executives in Scotland, Wales, Northern Ireland and London were popularly endorsed in referenda before being implemented. The same is true of some English devolution schemes outside London.

\section{Current weaknesses}

The overall UK-wide devolution project lacks any constitutional coherence. It has evolved piecemeal, in asymmetric and specific fashion in each case, making public understanding harder. The weaknesses of this mode of proceeding are demonstrated by the continuing constitutional clash over Brexit between the UK and Scotland, and the suspension of the unique Northern Ireland arrangements from February 2017 onwards forced by major parties refusing to cooperate.

Devolution deals in England have been negotiated in ways that lack transparency and have received little public scrutiny.

Turnouts in the new devolved mayor elections in England in May 2017 were somewhat lower than normal for local government (29\% in Greater Manchester for instance). But turnout in any elections for new bodies (that have not yet done anything, and whose responsibilities are little known) is often lower.

The English votes for English laws (EVEL) process has not created an institutional 'voice' for England. It remains an opaque and complex parliamentary procedure, little used, very little known, and even less understood by the general public (see Chapter 4.1). 


\section{Current strengths}

Stronger levels of citizen engagement with national legislatures have become the norm in Scotland and Wales, whereas they remain the exception at Westminster.

\section{Current weaknesses}

Inter-governmental relations between the devolved countries and the UK are very poorly developed, and do not include London. Perhaps as significantly, interparliamentary relations are vestigial.

\section{Future opportunities}

The Brexit process has already initiated another period of extensive constitutional flux. A positive consequence could be a window of opportunity to initiate an inclusive, nationwide deliberation about the constitutional future of the UK. So far, only a few Labour figures have called for such national conversation.

\section{Future threats}

There are concerns that as a result of the Brexit process, powers repatriated from the EU will accrue overwhelmingly to Westminster and Whitehall - as the original draft of Clause 11 of the EU Withdrawal Bill specified. To date the division of competences has only partially been resolved in outline. In April 2018, the Welsh government reached an agreement with UK ministers, but the Scottish government has not (see above). Critics argue that after the top-down Brexit process run by the May government devolution will be 'yet more variable and even more disjointed'.

As Wales moves from a conferred power model (where Westminster says what it could control) to a devolved power model (where responsibilities in broad policy areas rest with them by default, unless otherwise specified) so there may be a better constitutional alignment with devolution practices in Scotland.

If the UK government acts to repatriate powers from the EU honestly and in the spirit of subsidiarity, there are new opportunities for enhancing the powers and competences of all the sub-national legislative assemblies and governments.
Further territorial divisions within the UK could be amplified by a second Scottish independence referendum. This possibility depends on the level of public support north of the border, but also on the perceived treatment of Scotland's interests in negotiating the EU exit deal and the repatriation of powers.

The level of dispute and contestation both in the courts and politically has already clearly increased as a result of Brexit. A Westminster 'act alone', UK-centric approach to repatriation of powers, which seeks to evade proper parliamentary scrutiny and genuine involvement with the devolved legislatures, could pose a serious threat to the principles of democratic devolution. 


\section{Future opportunities}

The SV mayoral elections in future years will be opportunities to revitalise local democracy and to improve the visibility of devolution deals.

\section{Future threats}

The Conservative 2017 election manifesto unilaterally proposed scrapping the supplementary vote voting system used for elected mayors in London and various regions, and replacing it with first-past-thepost, which would radically lower the mayor's legitimacy. The manifesto is largely history now, but that such a non-consensus policy (also overturning local referenda) could have been envisaged by the Conservatives is an ominous sign for the future of English devolution.

\section{The further unfolding of Brexit}

As the Brexit process enters a new stage of detailed 'divorce' negotiations with the European Union, a raft of new legislation will be needed to give effect to the multiple changes involved. It will cover policy such as agriculture, fisheries, transport, and economic and environmental regulation where the three devolved countries are primary actors within their own territories. The Legislating for Brexit: White Paper (2017) suggested that existing EU frameworks will in the first instance be replaced by UK common frameworks, moving powers back to the UK centre. Subsequently, 'there will be an opportunity to determine the level best placed to take decisions [...] ensuring power sits closer to the people of the UK than ever before' (paragraph 4.5).

If a subsidiarity principle was followed in a full-hearted way, then devolved administrations and legislatures would see their functions and responsibilities greatly enhanced, and could play a vital role in the process. However, 'legislative consent' by the devolved countries went completely unmentioned in the White Paper, nor was there any indication of inputs to be made by the devolved legislatures. By April 2018, after many criticisms from the House of Lords and the opposition parties in the Commons, the UK government was still insisting that:

'The offer we put forward on clause 11 at Committee stage [of the EU Withdrawal Bill] would see the vast majority of powers flow directly from Brussels to Edinburgh, Cardiff and Belfast, just as the Scottish and Welsh Governments have argued. However, it is also vital we retain a mechanism to protect our internal market, our common resources, and our reputation as a credible international trading partner.'

\section{The Sewel convention and legislative consent}

If a Westminster MP seeks to ask a question of UK ministers about a matter that forms part of the devolved powers of the Scotland, Wales governments and Parliament/Assemblies (or those of Northern Ireland when operating) then the Speaker of the House of Commons will immediately intervene to rule the question out of order. So an outsider might have 
expected that Westminster would simply have stopped legislating about issues that are now controlled by devolved legislatures.

In fact that has not happened. Looking for a moment just at the UK-Scotland case, on about ten occasions a year, in every year that devolution has operated, the Westminster Parliament has legislated in ways that change the powers of the Scottish government and the Edinburgh Parliament. But in each case they have done so after a Legislative Consent Motion (LCM) was framed by the Scottish government and accepted by the Edinburgh Parliament. In almost all cases the effect of the legislation has either increased or left intact but varied in some way the powers of the Scottish government. And these changes have been accepted because they improve policy-making north of the border, maintain consistency across the two parts of the UK, and can conveniently be 'piggy-backed' on England and Wales legislation going through the Commons.

The Sewel convention is an agreement that 'Westminster would not normally legislate with regard to devolved matters in Scotland without the consent of the Scottish Parliament'. Initially rather informally established (like all other conventions), this was later formalised. A section of the Scotland Act 2016 clearly stated: 'It is recognised that the Parliament of the United Kingdom will not normally legislate with regard to devolved matters without the consent of the Scottish Parliament'. It also now applies to Wales in the same form.

However, the UK government's Devolution Guidance Note 10 interprets the Sewel convention very restrictively as follows:

'[W]hether consent is needed depends on the purpose of the legislation.

Consent need only be obtained for legislative provisions which are specifically for devolved purposes, although departments should consult the Scottish Executive on changes in devolved areas of law which are incidental to or consequential on provisions made for reserved purposes'

(paragraph 2).

The difference between these two views is quite wide legally. For example, Mark Elliot has argued that if the Westminster government wanted to withdraw the whole UK state from the European Human Rights Convention (as the Conservatives in 2015-17 said they wished to do), then it could so - because the action does not relate solely to devolved powers (as Brexit does not). However, what Westminster could not do within the Sewel convention was then to put in place a 'British Bill of Rights' (as the Conservatives at one stage planned to do) - because this would vary the powers of the devolved country administrations and require their legislative consent. We have seen (above) that it remains to be clarified if the specific repatriation of powers from the EU proposed by the May government by summer 2018 falls foul of the Sewel convention or not.

\section{The growing powers of the devolved governments}

As late as 2017 the varying powers of the devolved governments could still be diagrammed relatively easily, as in Figure 3 - which shows the proportion of each Whitehall department's duties assigned to Scotland, Wales and Northern Ireland (if its devolved 
mechanisms were working, and not suspended, as at present). At the top of Figure 3 are 'domestic' departments where most powers were devolved, and at the bottom are the UK's outward facing ministries where nothing was then devolved. In between there was not much of a spread. A few Whitehall departments retained some minority powers in Scotland and Wales, while a few other central departments had ceded minute fractions of their role to the devolved governments. So the idea of a 'clean split' still confronted anomalies, such as Northern Ireland having zero control over justice, due to earlier sectarian problems; or Scotland and Wales having fewer Cabinet Office roles than Northern Ireland.

Figure 3: The estimated proportion (\%) of each Whitehall departments' functions devolved to the three nations in 2017

\begin{tabular}{|c|c|c|c|}
\hline $\begin{array}{l}\text { Percent of each } \\
\text { department's } \\
\text { work devolved }\end{array}$ & Northern Ireland & Scotland & Wales \\
\hline $99-100 \%$ & \multicolumn{3}{|c|}{$\begin{array}{l}\text { Department for Education; Department for Communities, Housing } \\
\text { and Local Government; Department for Health; Department for } \\
\text { Environment, Food and Rural Affairs }\end{array}$} \\
\hline $100 \%$ & \multicolumn{3}{|l|}{ Ministry of Justice } \\
\hline $100 \%$ & \multicolumn{2}{|l|}{$\begin{array}{l}\text { Department for Work } \\
\text { and Pensions }\end{array}$} & \\
\hline $91-92 \%$ & \multicolumn{3}{|c|}{ Home Office; Department for Transport } \\
\hline $81 \%$ & & & $\begin{array}{l}\text { Department for } \\
\text { Transport }\end{array}$ \\
\hline $79-80 \%$ & \multicolumn{3}{|c|}{ Department for Digital, Culture, Media and Sport } \\
\hline $10-15 \%$ & \multicolumn{3}{|c|}{ Business, Enterprise, Innovation and Skills } \\
\hline $4-5 \%$ & Cabinet Office & & \\
\hline $1-2 \%$ & & \multicolumn{2}{|c|}{ Department for Work and Pensions } \\
\hline Less than $1 \%$ & & \multicolumn{2}{|c|}{ Cabinet Office } \\
\hline Less than $1 \%$ & \multicolumn{3}{|l|}{ HMRC, HM Treasury } \\
\hline Zero & & & Ministry of Justice \\
\hline Zero & \multicolumn{3}{|c|}{$\begin{array}{l}\text { Ministry of Defence; Foreign Office; Department for Exiting the EU; } \\
\text { Department for International Trade; Department for International } \\
\text { Development }\end{array}$} \\
\hline
\end{tabular}

Source: Rearranged from Institute for Government, 2017 
The mixing and overlap of roles is certain to increase because of changes already made to stave off Scottish independence in 2014. Figure 4 shows that the devolved governments have each received substantial tax-setting powers, with more to come in stages until 2019, and that their administration has been put in place over recent years. So a substantial set of powers are moving from HM Treasury.

\section{Figure 4: Tax devolution since 2014}

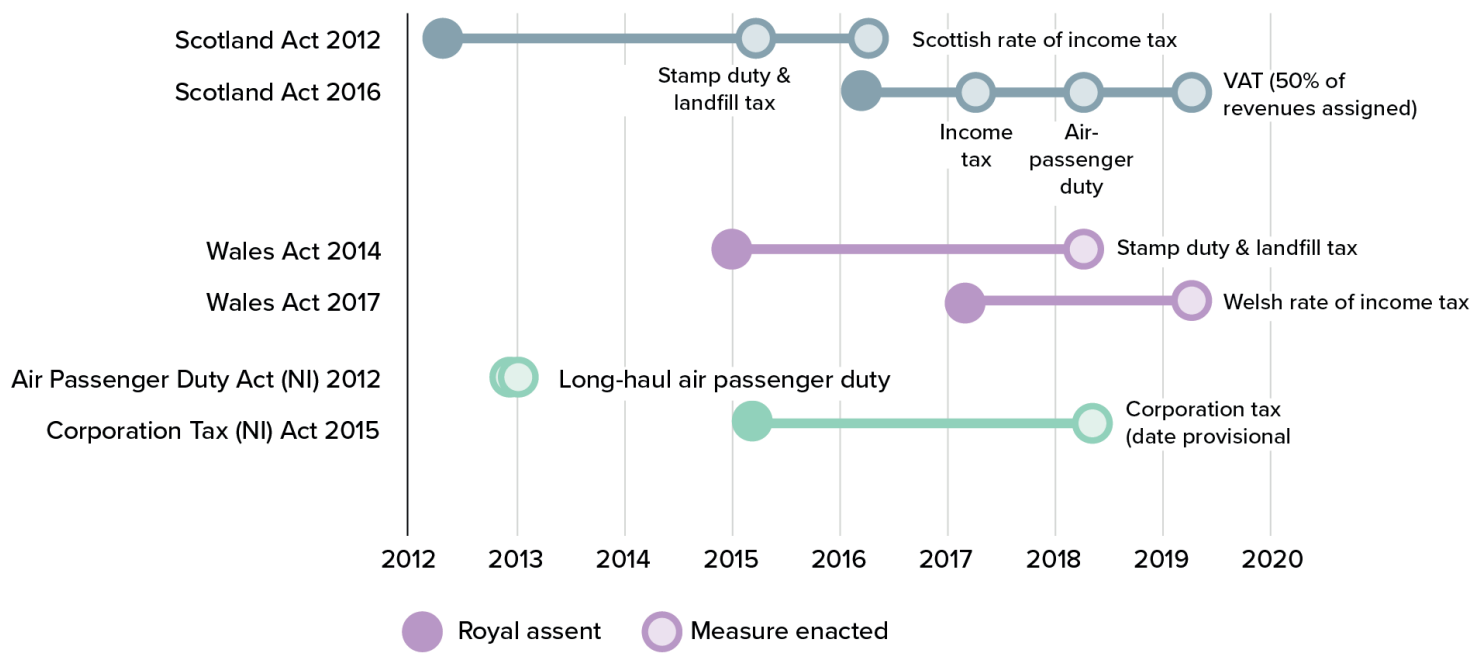

Source: Institute for Government, Whitehall Monitor 2018, Figure 3.16

How the Brexit process works through in the probably extended period it takes the UK to separate from the EU will also affect the further blurring of functions across the two tiers. Arrangements are only likely to get more complex, as away from the headline disagreements, the two tiers of government have already:

'Agreed to the principle of establishing UK-wide "common frameworks" in key areas. For their part, UK ministers have repeatedly committed to the idea of some EU powers being exercised exclusively at devolved level after Brexit, and have now backed away from placing a reservation on "retained EU law".

\section{Conclusions}

Devolution in Scotland, Wales and London has strengthened representation, legitimacy and the inclusiveness of policy debates there. It also played a key role in Northern Ireland, and is likely to do so again, although arrangements there have been suspended now for 18 months. Devolution in England outside London to regional and metro mayors has just begun but may help redress important democratic and scrutiny deficits within some parts of England. However, all types of devolution still lack clarity and coherence, with poor 
inter-institutional relations and questionable constitutional and legal protections for even devolved powers in Scotland (the most powerful devolved country). As a result, the overall durability of democratic devolution in the UK seems still unsettled.

Diana Stirbu is a Senior Lecturer in Public Policy at London Metropolitan University.

Patrick Dunleavy is Professor of Political Science and Public Policy at the LSE and codirector of Democratic Audit there. He is also Centenary Professor in the Institute for Governance and Policy Analysis (IGPA), University of Canberra. 